\title{
Connessioni tra città e immagini per tessere inediti legami sociali
}

\author{
Pia Davico
}

\section{Abstract}

Negli ultimi tempi le città stanno sempre più adottando, in progetti di riqualificazione urbana e sociale, opere di Street Art, creando legami tra spazio, architettura e immagini, nonché tra il centro e le zone periferiche. Legami anche involontari, creati da percorsi visivi fittizi, dovuti alla ricerca e scoperta di scorci della città sempre nuovi, caratterizzati da disegni in genere pieni di colori e di grandi dimensioni, che divengono protagonisti dell'ambiente. I vari interventi, sia voluti da progetti coordinati sia spontanei, documentano tutti il cambio di ruolo di un'arte ritenuta sino a pochi anni fa del tutto illegale, e che oggi, con i caratteri pregnanti dei suoi disegni spettacolari, diviene un motore di sensibilizzazione a temi sociali, smuovendo la coscienza collettiva più di tante parole. Tali creazioni, in modi differenti, definiscono un vero legame tra più componenti dell'ambiente e i suoi abitanti, rispecchiando le parole del noto matematico e fisico Jules Henri Poincaré, per il quale la "Creatività è unire elementi esistenti con connessioni nuove che siano utili".

In un tale panorama generale dai confini molto ampi si collocano varie esperienze, accomunate da intenzioni e significati nei quali il termine "connessione", tema del Convegno, trova eco in diverse forme progettuali; la città stessa, attraverso la Street Art, si fa portavoce del desiderio di sensibilizzare la società a intessere legami (di vario genere) per sconfiggere le distanze tra uomo e ambiente e tra uomo e uomo.

\section{Parole chiave}

disegno, Street Art, spazio urbano, connettere, distanze sociali.

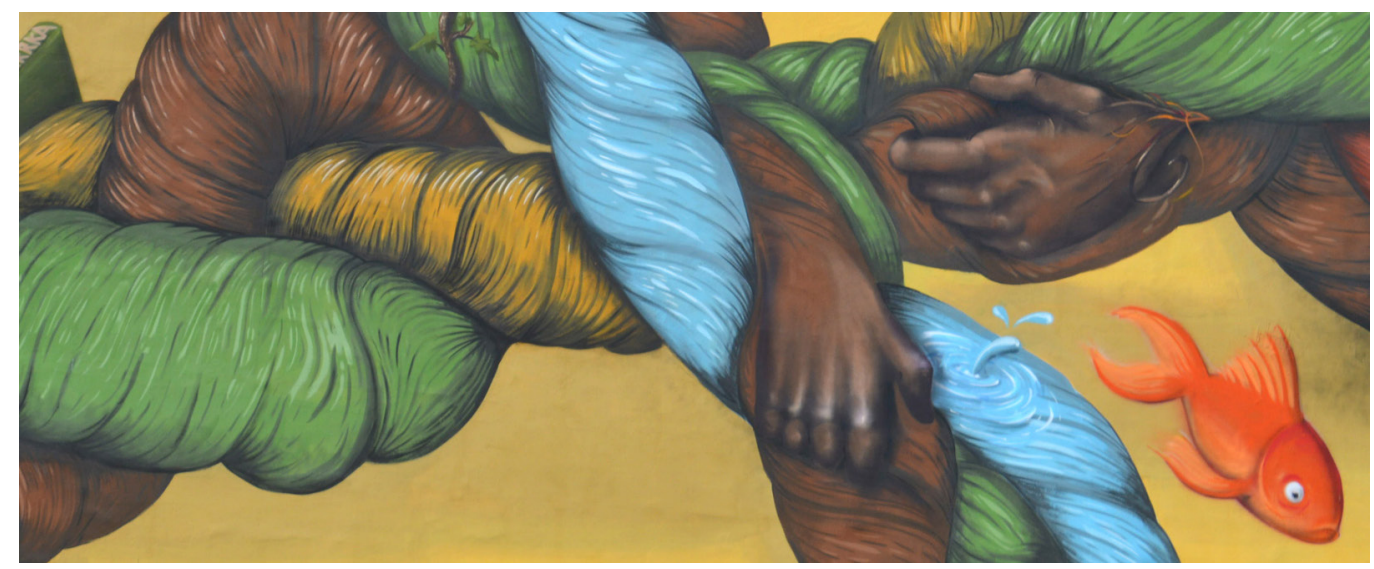




\section{Introduzione}

Sono sempre più numerose le città che affrontano nuovi scenari urbani attraverso la Street Art, riconoscendole un ruolo importante nel catalizzare nuove dinamiche, sociali e turistico-fruitive, e nel riqualificare luoghi degradati.

Questo tipo d'arte stenta ancora a essere riconosciuto pienamente nell'ambito dell'arte e della legalità, liberandosi da un passato nel quale era condannata come un atto vandalico [l]; molti paesi e città di tutto il mondo la stanno tuttavia adottando a ritmi crescenti per proporre progetti migliorativi dei luoghi e della società, avendone compreso e testato le ricadute positive non solo a livello di immagine. Vengono infatti proposti sempre più di frequente, dalla scala locale a quella internazionale, tanto progetti d'intervento coordinato (tra street artists, amministrazioni e associazioni culturali) guidati da un preciso obiettivo, quanto singoli interventi puntuali su edifici degradati o muri spogli. Gli uni e gli altri stanno gradualmente configurando veri musei a cielo aperto, caratterizzati da un ciclo vitale mutante nel tempo, anche solo per il degrado delle opere dovuto alle intemperie.

I disegni e i dipinti, generalmente, caratterizzano elementi dell'architettura privi di una propria identità - come fronti ciechi, muri divisori o edifici abbandonati - e li riqualificano con una nuova veste e un nuovo ruolo all'interno dello spazio urbano. II successo di queste opere è però legato non solo alla creazione di una nuova immagine ambientale, ma anche all'immediatezza con la quale trasmettono messaggi, abilmente individuati e interpretati dagli artisti, che arrivano in modo diretto alla gente. Questi messaggi spesso vengono proposti, volutamente, in luoghi degradati fisicamente e socialmente, come auspicato innesco di dinamiche migliorative e di riscatto, togliendo dall'isolamento intere aree delle città e i loro abitanti; in molti casi la popolazione viene coinvolta in progetti partecipati o, più in generale, se ne richiama l'attenzione su temi di interesse collettivo, dando voce indirettamente a tante persone silenziose.

Luoghi e persone oscurati da una storia spesso 'ai margini' trovano quindi una nuova identità, stimolati da immagini e significati delle opere che diventano fulcri dell'ambiente e di dinamiche comportamentali; si innescano così processi aperti a scenari di coinvolgimento anche in ambito turistico, creando altresì connessioni culturali e artistiche tra centro città e periferia, con positive ricadute urbane e sociali. Si creano infatti, intenzionalmente o casualmente, percorsi che legano le opere tra loro e con parti di città rimaste a sé stanti per la loro storia o conformazione.

Di questa realtà, sempre più legata alla riqualificazione urbana, ho selezionato qui di seguito alcune opere che interpretano in modi diversi una comune volontà: marcare l'importanza dei legami sociali, suscitando stupore ed emozioni, e creando altresì un fenomeno che confermi l'asserzione di John Trackara: "le città più emozionanti sono quelle dove succedono cose inaspettate, in luoghi inaspettati e tendenzialmente poco belli e marginali" [2].

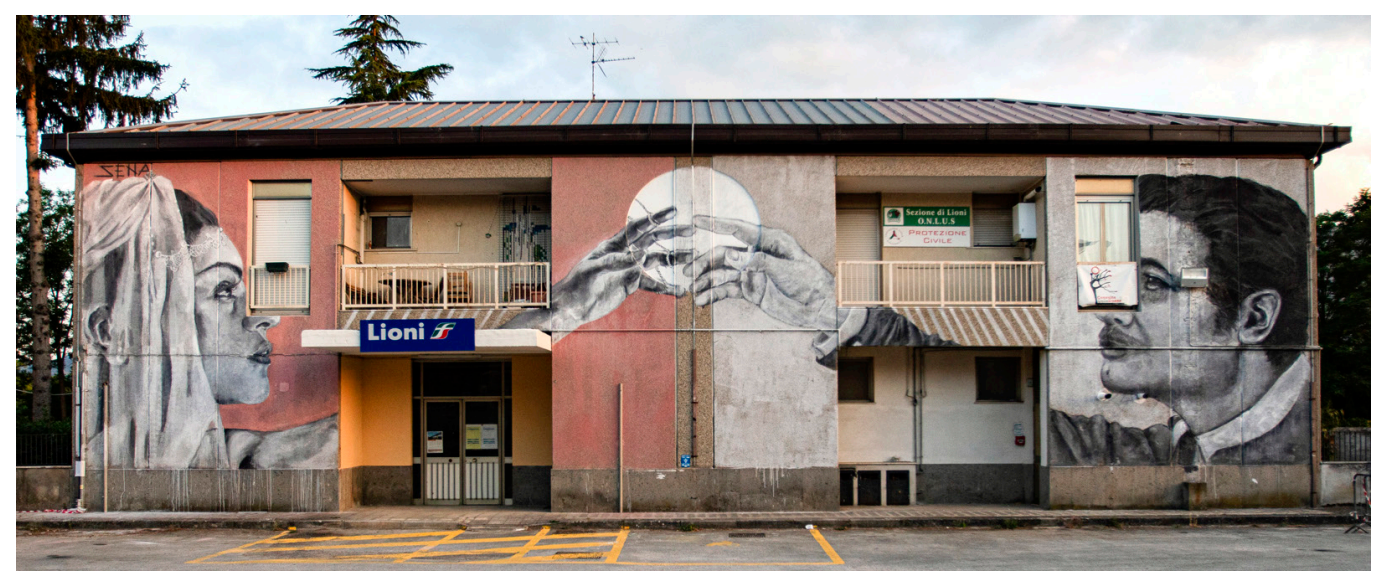




\section{Unire le distanze tra gli uomini}

É tuttora vivo nella memoria collettiva il terremoto dell'Irpinia: a distanza di quarant'anni il comune di Lioni nei mesi scorsi ha realizzato, con l'associazione di promozione sociale La Prediletta, il progetto di arte urbana 1980-2020 Prospettive d'autore. L'unione tra le persone' vi è stata interpretata in due murales dal diverso significato: Legami di Antonio Sena e Folle del Collettivo Fx e NemO'S. La prima opera (fig. I) è realizzata sul fronte della stazione ferroviaria, in ricordo di quanti hanno vissuto le partenze migratorie del secolo scorso; configura i volti e le mani che si sfiorano di un uomo e di una donna. II simbolismo del volto femminile avvolto in un velo e della sua mano annodata da un laccio riporta alla condizione femminile nelle società rurali del sud, quando il matrimonio per procura era molto diffuso e segnava le vite con distacchi e ricongiungimenti. Una cesura, dunque, tra un prima e un dopo che, analogamente, si ritrova nell'altra realizzazione di arte urbana a Lioni (fig. 2), interessante per come propone un disegno con una lettura a più scale, nel quartiere popolare Campo Bergamo. E un'opera di forte significato, che annulla le distanze e rimarca, attualizzandolo, il consolidato legame di solidarietà con la città lombarda che aveva supportato la realizzazione dell'omonimo quartiere irpino dopo il terremoto; città che quest'anno è stata a sua volta provata dalla pandemia del Covid, a cui Lioni si stringe simbolicamente attraverso il murale. Nel disegno, infatti, due mani protese a stringersi sono formate da centinaia di omini che rappresentano le due comunità, legate in un abbraccio virtuale [3].

Un abbraccio è stato invece materialmente negato, da alcuni anni, con la costruzione del muro tra Messico e Stati Uniti, contro il quale hanno risposto vari street artists, come Enrique Chiu, che con il progetto Mural of brotherhood lo ha reso una quinta vivacizzata da disegni e scritte che promuovono l'unione e la pace (fig. 3) [4]. Nel 2017 lo stesso muro ha per un mese accolto l'opera più provocatoria del writer francese Jr, con la gigantografia di un bimbetto messicano, Kikito, che dal suo Paese, lungo la frontiera che separa il Messico da San Diego, si affaccia guardando al di là di quel lungo muro che per chilometri si impone nel paesaggio (fig. 4). L'immagine è divenuta un simbolo contro le divisioni, per il suo gigantismo (venti metri di altezza) e la forte espressività, e ha sovvertito l'impatto di quella barriera che ha separato vite e affetti, configurando la volontà di molti di non accettare quel muro e, più in generale, le barriere che impediscono il contatto e la libertà degli esseri umani.

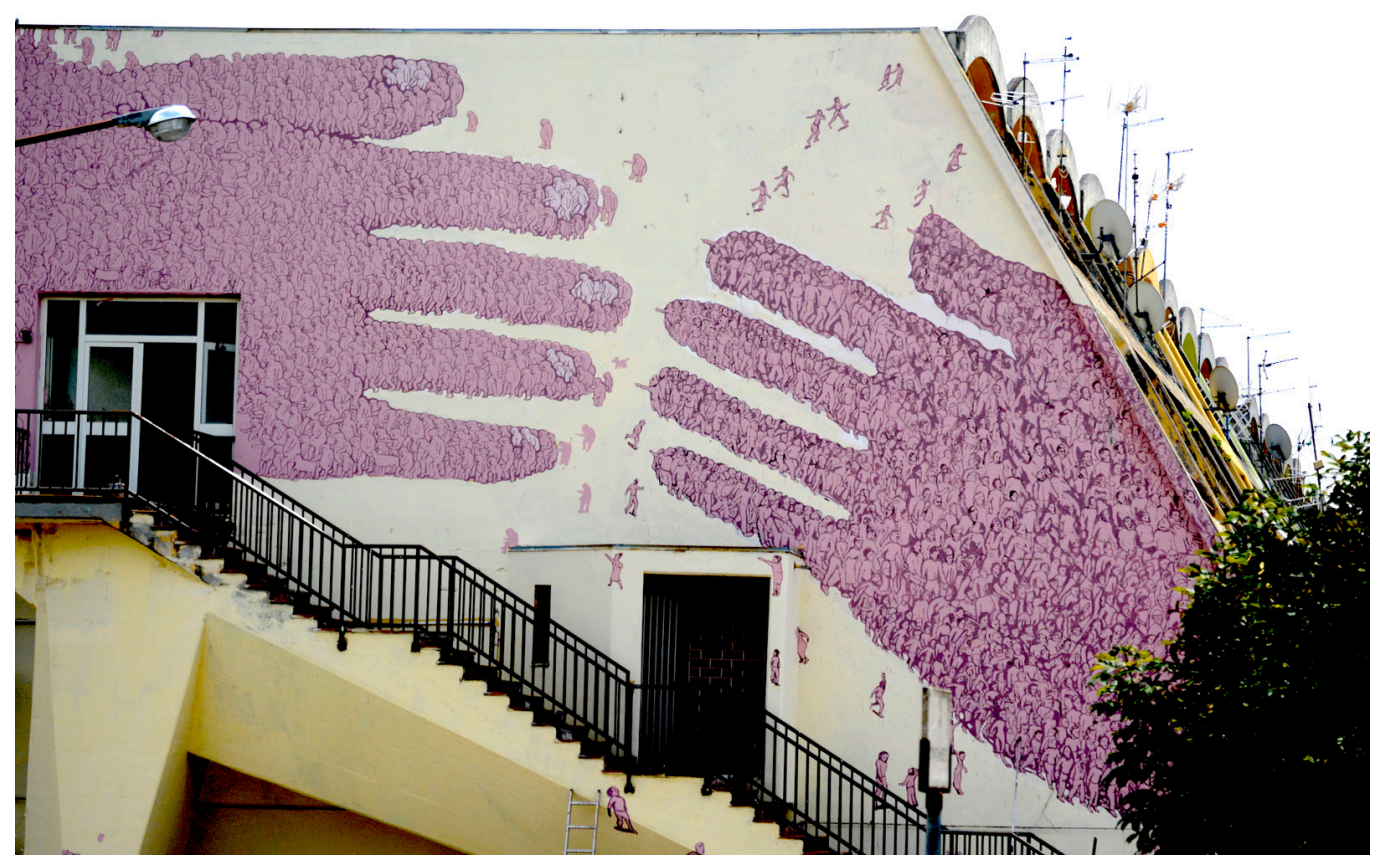


Fig. 3. Enrique Chiu, Mura of brotherhood, muro tra Messico e Stati Uniti

$<$ https://thevalemagazine. com/2019/07/07/muralof-brotherhood-enriquechiu-us-mexico-border/ (consultato il 20 marzo 2021)

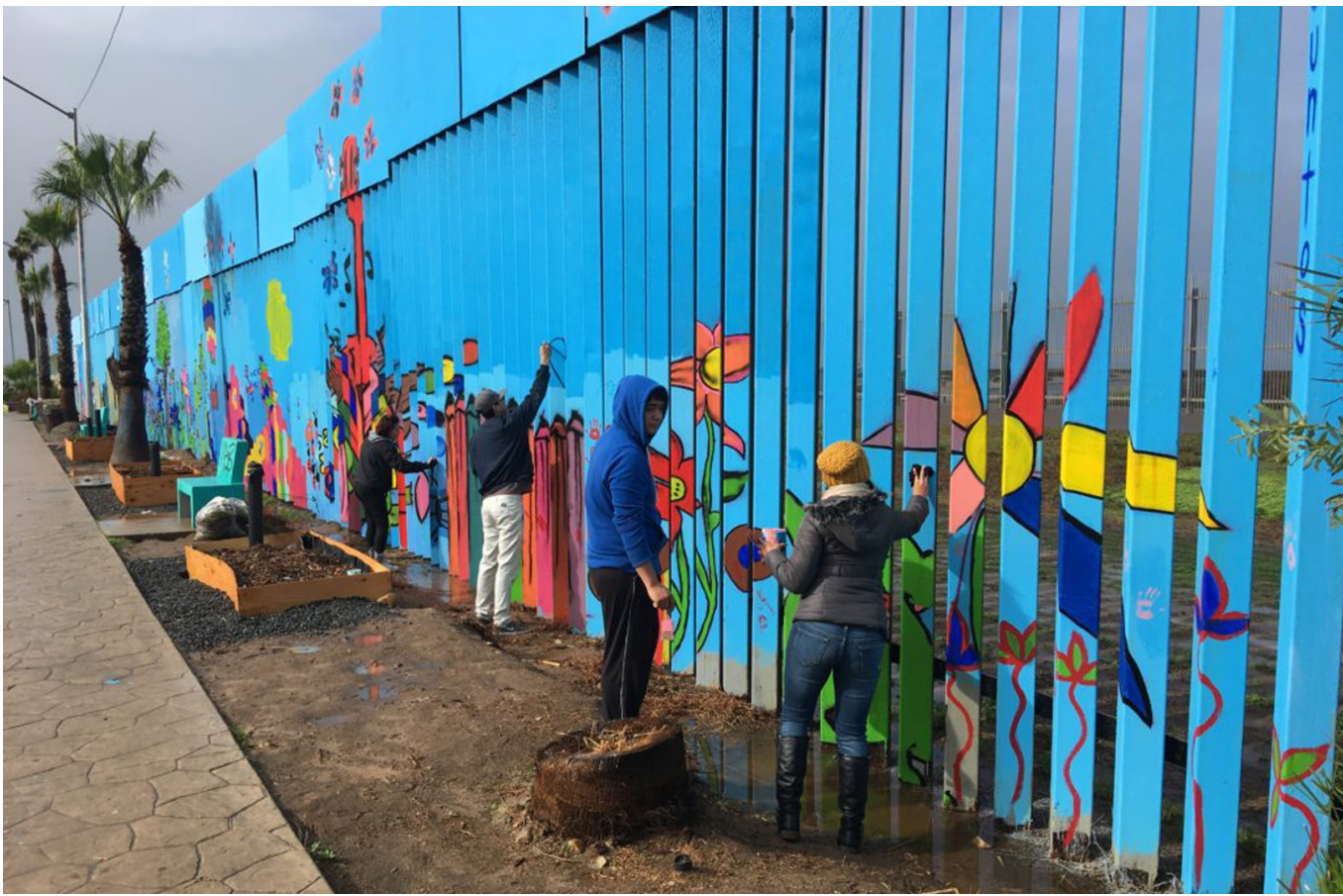

Oltre a queste divisioni di tipo fisico vi sono poi barriere invisibili che distanziano le persone, derivanti da problematiche sociali, spesso superate con progetti di arte urbana che ne abbattono le dinamiche sbagliate. Ne è un esempio probante l'intervento recente realizzato nel quartiere Palmitas della città messicana di Pachuca, nato dalla collaborazione tra il Governo e il collettivo Germen Crew e Comex, che ha creato coesione nella comunità locale e diminuito la violenza giovanile (fig. 5). Un enorme murale dipinto da writers e dagli stessi abitanti ha avvolto case e strade in un arcobaleno di colori, che personalizza il paesaggio con l'articolazione su un'altura dell'intero nucleo urbano e ogni suo scorcio e singolo edificio, connotando l'identità del luogo e delle stesse persone, la cui abitazione risulta un unicum entro un'immagine comunitaria [5]. L'apparente semplicità di questo progetto, attentamente calato in una realtà ove il colore è un elemento radicato culturalmente, trova un senso profondo nelle parole dell'antropologa americana Jane Jacobs per la quale "Progettare una città da sogno è facile [...] É ricostruirne una vitale che richiede fantasia" [6].

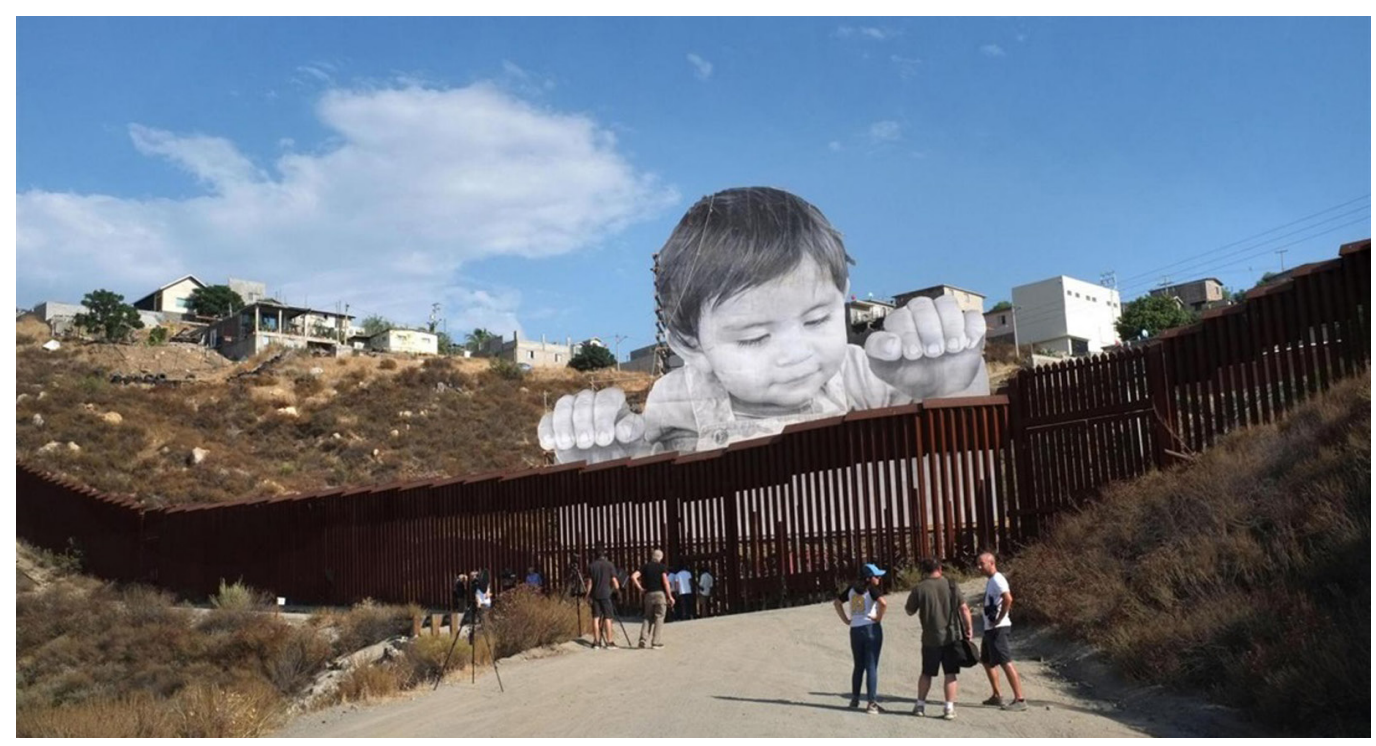


Fig. 5. Collettivo Germen Crew e Comex, Quartiere Palmitas, Pachuca (Messico) <https:// danatahal l.wordpress. com/2015/08/04/ germen-crew-creates-agiant-piece-in-pachucamexico/> <https:/ foolsiournal2 wordpress. com/20 17/04/13/stres. art-latiot messicol $>$ (consultato it 20 marzo 2021).
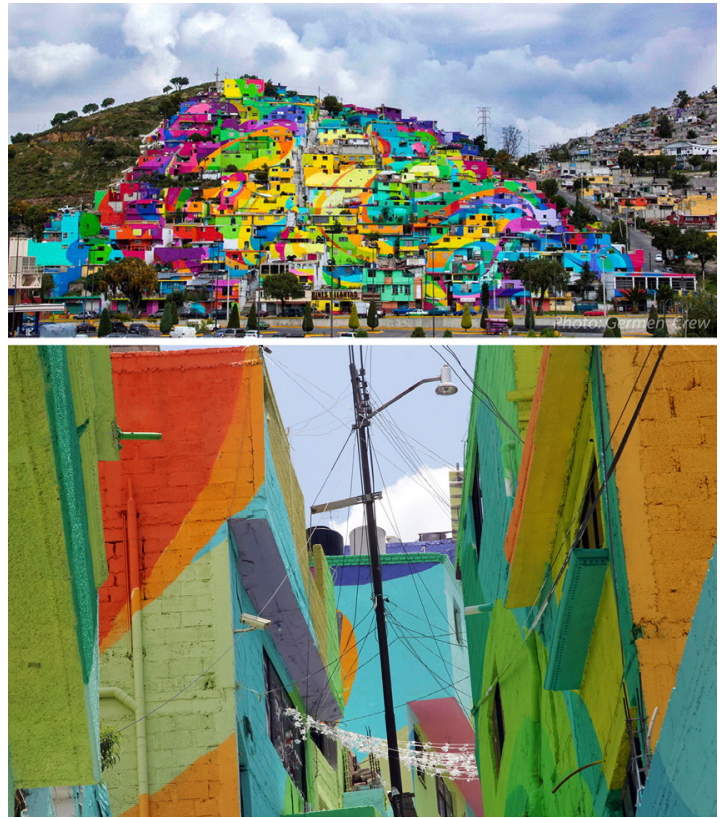

\section{Connettere gli strappi nella vita dell'emigrato}

Tra le distanze della società odierna, quella creata dall'emigrazione è quanto mai attuale, ed è il tema di numerose opere di arte urbana in Italia e nel mondo, finalizzate a richiamare l'attenzione su un dramma umano diffuso e che pare non aver fine. Tra i tanti interventi propongo The Mediterranean tunnel dello street artist francese MTO (fig. 6), particolarmente rappresentativo e originale per come crea il legame tra due coste, costrette a spartirsi i profughi o i loro cadaveri. É un'opera 'spezzata' sui fronti di edifici di due città, connesse al contempo in un progetto interpretativo delle 'divisioni' dal significato pregnante. Nel muro di una casa a Sliema (costa orientale di Malta), da uno squarcio disegnato fuoriescono le
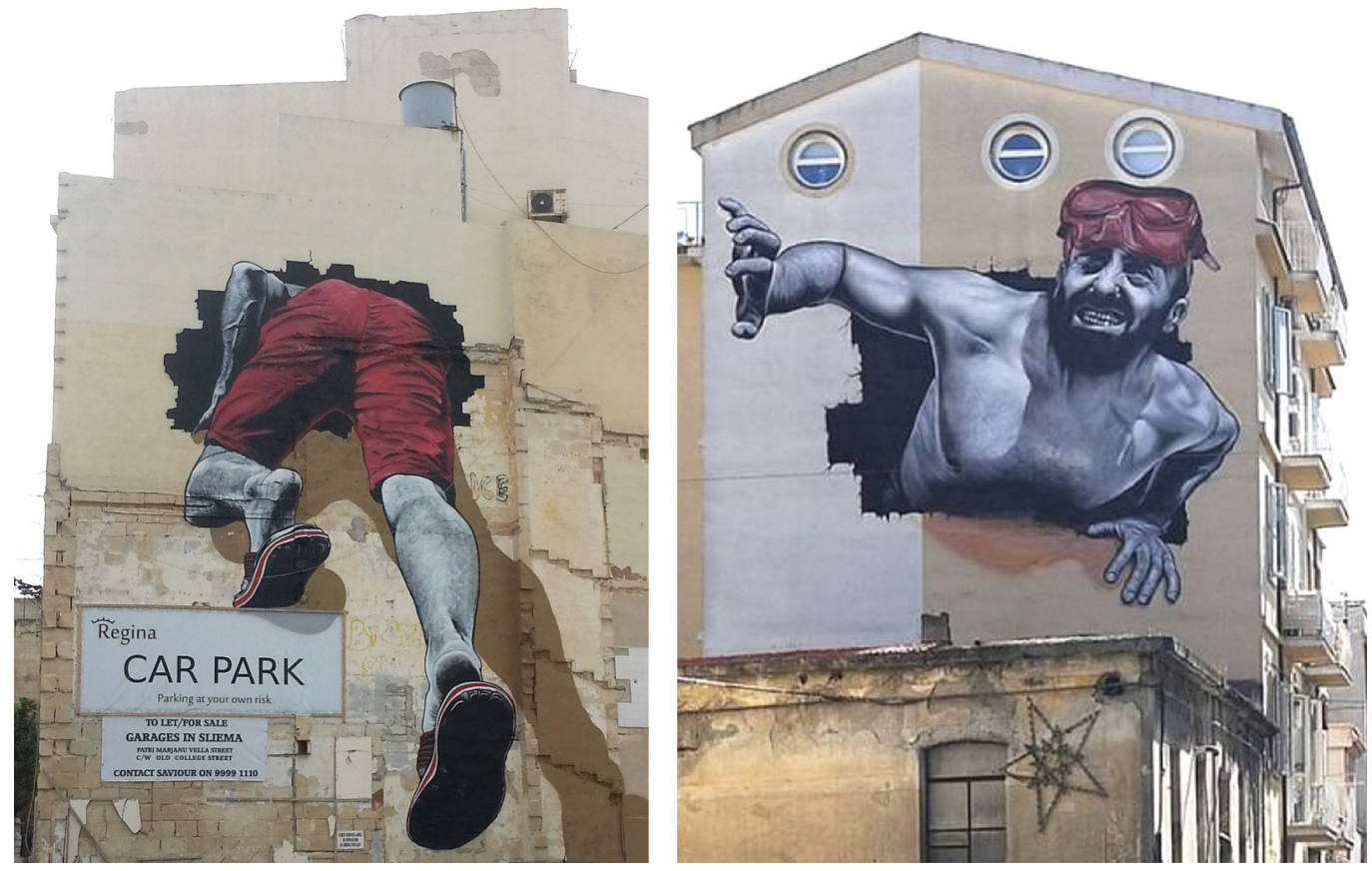

Fig. 6. MTO, The Mediterranean tunnel, di Malta) e Sapri (cost salernitana) $<$ https $/ /$

twistedsifter.com/2015/08

the-mediterranean-tunnel-

by-mto/> (consultato il 20 marzo 202I). 
Fig. 7. Smoe, Emigranti, Catanzaro <http:// www.smoe.it/outdoor/ emigranti/> (consultato il 20 marzo 202I).
Fig. 8. Smoe, Meridianam, Catanzaro <https:// wuw.citynow.it/ riace-nel-mondo-spiccamelbourne-muralemade-calabria-marchiatosmoe/> (consultato il 20 marzo 2021) gambe di un uomo intento a entrarvi faticosamente, mentre a seicento chilometri di distanza, su un fronte a Sapri (costa salernitana), fuoriesce da una spaccatura il profugo, con il volto sofferto nella gestualità affaticata di liberarsi. II doppio disegno sintetizza la realtà spezzata da un viaggio lungo e pericoloso e al contempo crea un legame virtuale a distanza, connotato da una espressività gestuale che s'impone nel caratterizzare l'ambiente circostante, sottomettendone i caratteri architettonici.

Tra le tante altre opere riguardanti l'emigrazione, che meriterebbero una trattazione ampia per come evidenziano la priorità dell'interesse, grafico e non solo, al tema, cito ancora Emigranti (fig. 7), un murale di Smoe (purtroppo già sottoposto al degrado) che su un banale muro di contenimento a Catanzaro ha creato, attraverso un abile disegno prospettico, un legame tra i flussi migratori del passato e quelli del presente. A questi ultimi l'autore ha dedicato il più recente Meridianam (fig. 8) dando voce attraverso le immagini al fenomeno più recente, gravido di un dolore immenso e di tragedie disumane [7].
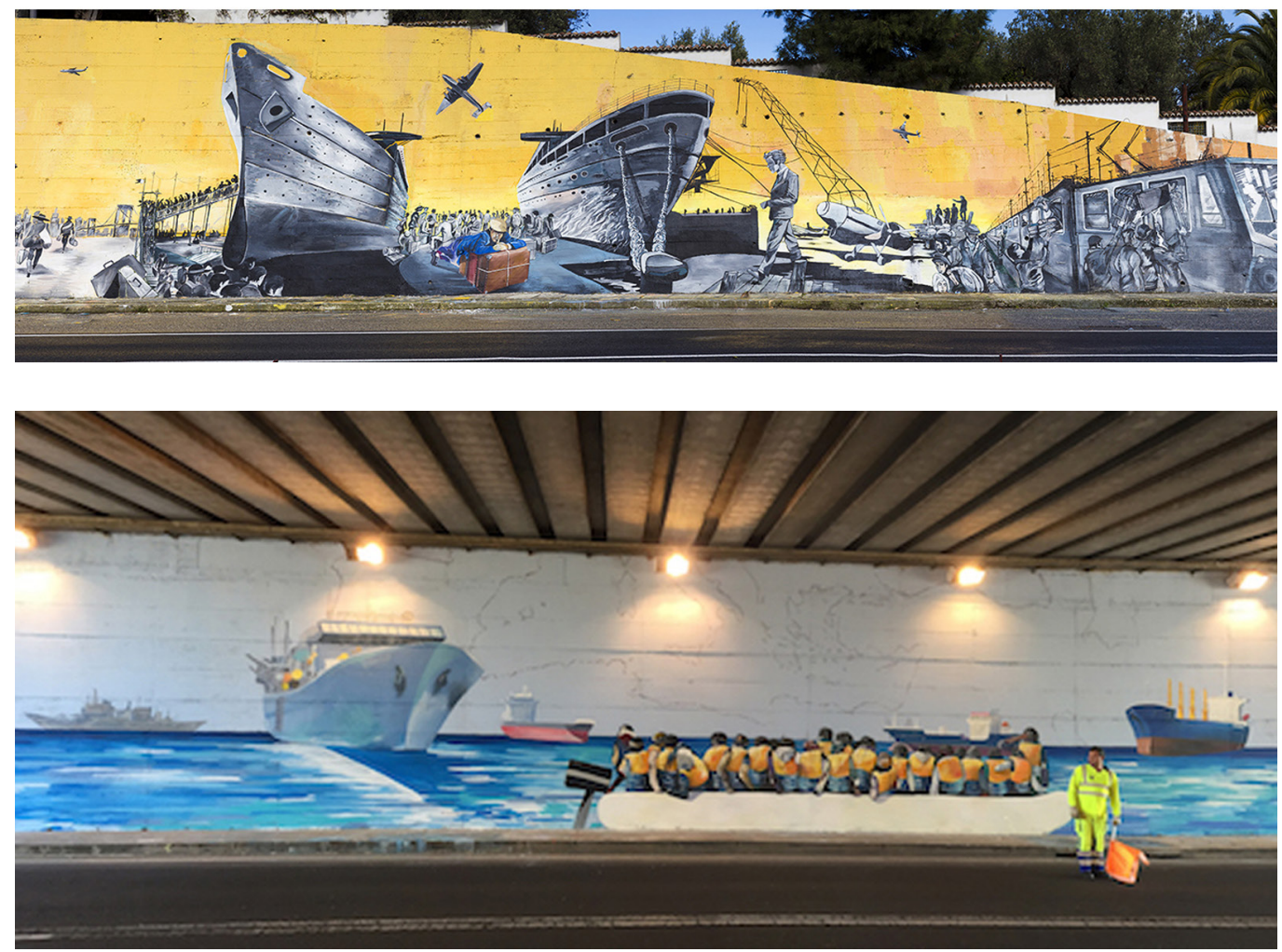

Creare legami tra gli uomini, la città, il mondo

I disegni, i colori e le immagini in grado di generare dal nulla quei legami, visivi, culturali e sociali, sin qui citati, dalla forte intensità comunicativa, si espandono oltre il loro confinamento materiale, creando nuovi rapporti ad ampio raggio che, talvolta, agiscono in dinamiche a scala mondiale. II successo internazionale della Street Art nel diffondere temi coinvolgenti le comunità si ritrova in molteplici progetti con caratteri e finalità diversi. Qui ne propongo alcuni che, in diverse forme, sottolineano l'importanza dei legami tra gli uomini, l'intorno, e il resto del mondo. Desidero iniziare da un'immagine che esalta questo significato, appartenente al complesso progetto di Street Art TOward 2030. What are you doing? che dal 2019 ha inserito nel tessuto urbano torinese opere che interpretano gli obiettivi di sviluppo sostenibile dell'ONU (Sustainable Development Goals) [8]. II murale del Goal 17 Partnerships for the goals (fig. 9), di Monkeys Evolution, caratterizza non solo il fronte cieco di un palazzo ma tutto l'ambiente circostante, imprimendo sul fondo giallo intenso il disegno di corde 
Fig. 9. Monkeys Evolution, the goals, Torino (foto di Pia Davico, luglio 2020)

Fig. 10. Opera di Murales Resilienti, progetto REACT, Guatemala $<$ https://www.weworld.it/ iniziativa-dei-murales-resilienti/> (consultato il 20 marzo 202I)
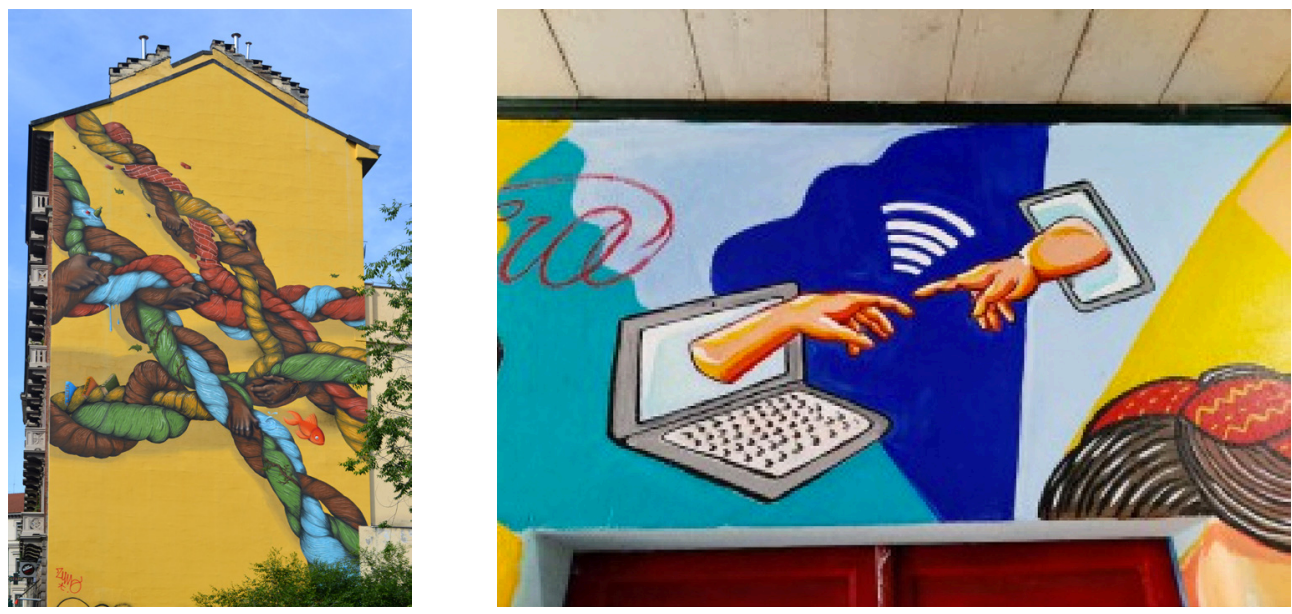

colorate e mani che si intrecciano. L'opera, in corso Giulio Cesare 20, in una zona della città che accoglie immigrati di varie etnie, sottolinea simbolicamente come la rete delle azioni congiunte di uomini di diverso 'colore' arricchisca la nostra società e la nostra cultura e, nello specifico, permette di raggiungere ogni goal, a livello locale e mondiale.

L'obiettivo analogo di unire valori e superare distanze con progetti sociali che utilizzano l'arte urbana per arrivare a chiunque, si riscontra nel progetto Murales Resilienti che ha preso vita in Guatemala nei mesi scorsi: otto opere di giovani writers locali promuovono valori della resilienza e della solidarietà stimolando relazioni umane e aiuto reciproco. Si distingue, per l'originalità nel trattare il periodo che il mondo sta vivendo per la pandemia Covid, il murale che cita giocosamente la michelangiolesca Creazione di Adamo nella Cappella Sistina, configurando due mani intente a sfiorarsi mentre fuoriescono dai video di computer e tablet. Sottolinea cosi il ruolo fondamentale della tecnologia nell'aver permesso, nel periodo di isolamento pandemico, di unire le distanze tra gli uomini (fig. I0) [9].

Concludo citando ancora due murales, di diversa origine e lontani nel tempo, che esaltano il valore aggiunto dell'unione tra gli esseri umani, realizzati in un caso da Cristian Sonda con i ragazzini che frequentano la Casa per fare insieme di Rozzano (MI) (fig. I I), nell'altro da un artista di fama internazionale come Keit Haring, a Pisa (fig. I 2). A distanza di anni infatti (il primo è stato realizzato pochi mesi fa, l'altro nel 1989) sottolineano entrambi, con disegni ariosi e pieni di colori vivaci, la bellezza di una comunità arricchita dalle diversità delle persone, come input educativo e di sensibilizzazione [10].

Questi stimolanti obiettivi a scala internazionale sono sempre promossi da immagini dal forte simbolismo, il cui successo risiede nello stupore che suscitano, nell'immediatezza comunicativa, e nel fornire spesso un raggio di speranza, soprattutto a quegli ambienti che subiscono le conseguenze dell'abbandono.

Fig. I I. Cristian Sonda e ragazzini della Casa per fare insieme, Rozzano (MI) https://zh-cn. facebook.com/casaperfareinsiemerozzano/ posts/grazie-cristian-sonda-e-grandi-ragazze-e-ragazzi-della-casa-texere/321980031785885/ (consultato il 20 marzo 2021).

Fig. 12. Keit Haring Tuttomondo, Pisa <https:// www.contemporaryno$\mathrm{mad} . \mathrm{com} /$ keith-harings-pimad.com/keith-harings-pisa-muraltuttomondo 202I)
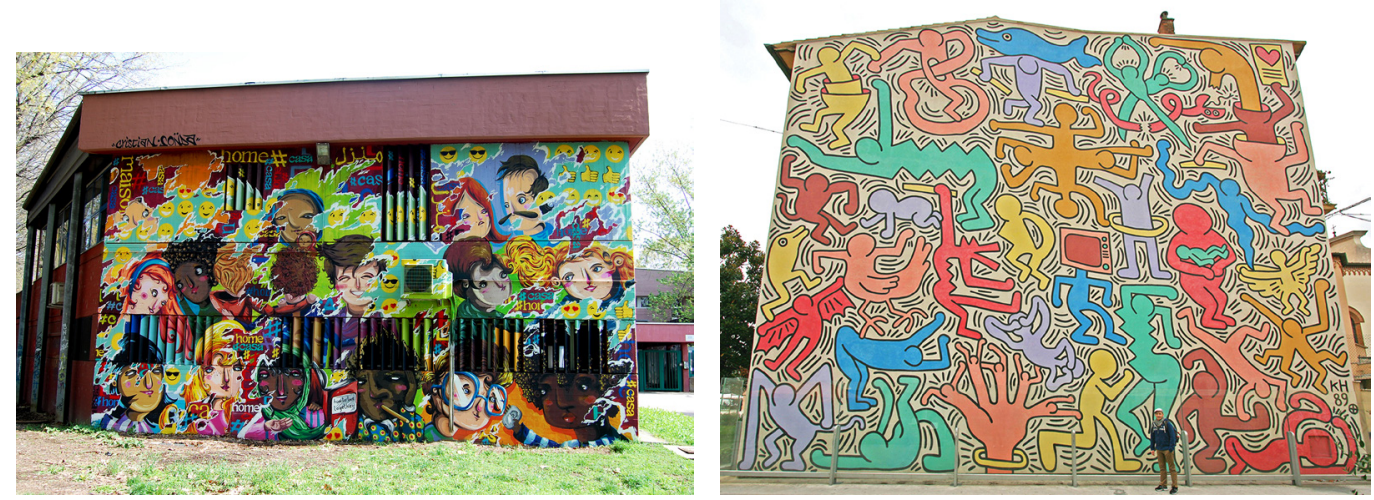
Sono immagini che creano un forte legame di immedesimazione con le persone e con le città: le opere ne divengono protagoniste di una nuova identità ambientale, in cui i caratteri delle architetture si offuscano, diventando semplici supporti di grandi 'tele' urbane. I loro significati si insinuano come elemento di denuncia e di speranza nella vita degli uomini e nelle dinamiche della città, con quella creatività che, per usare le parole di Jules Henri Poincaré consiste nell' "unire elementi esistenti con connessioni nuove che siano utili".

\section{Note}

[I] Per un approfondimento di questo aspetto cfr. Colantonio 2017.

[2] inforum. Informazioni sulla Riqualificazione Urbana e Territoriale, n. 39, 2012, p. 33.

[3] Oltre a questi Lioni propone altri murales, entrando nel circuito Musei Urbani di Google Art per il nuovo flusso turistico creato dalla Street Art. Dal 2014 è nota, infatti, per il festival di arte urbana, attento a vari temi sociali (come i due murales di Dale Grimshaw che nel 2018 hanno scatenato polemiche proponendo il tema più che mai attuale dei migranti odierni).

[4] II progetto, che dal 2017 ha coinvolto per circa due anni migliaia di volontari, si estende lungo mille chilometri, incarnando il pensiero di Chiu per il quale "l'arte è una opportunità per dire cose che sconfinano".

[5] II murale, realizzato per cambiare il destino di un quartiere degradato, copre una superficie di 20.000 metri quadrati, distribuita su più di duecento case.

[6] II tema specifico del colore come elemento di caratterizzazione dei nuclei urbani è trattato in: Davico Pia, 2013. II ruolo strutturante del colore per la caratterizzazione di ambiti urbani. In Rossi M., Siniscalco A. (a cura di). Colore e colorimetria. Contributi multidisciplinari, vol. IX A, pp. 389-400Santarcangelo di Romagna: Maggioli editore.

[7] Smoe è uno street artist catanzarese, attivo in varie parti del mondo sui temi dell'immigrazione e delle minoranze. In Meridianam ha concentrato l'attenzione sulle migrazioni odierne nel Mediterraneo e su quelle dal sud Italia di molti giovani in cerca di lavoro.

[8] II progetto, nato dall'intesa tra la Città e la Lavazza e inaugurato nel gennaio 2020, ha collocato i murales sia in centro sia in periferia, per creare un ampio coinvolgimento ai temi specifici della sostenibilità, proiettando Torino all'interno di un dibattito a scala mondiale, come prima metropoli al mondo ambasciatrice dei 17 Obiettivi di sviluppo sostenibile delle Nazioni Unite.

[9] L'iniziativa è parte di un ampio progetto di aiuti umanitari che coinvolge diversi enti, articolato in vari tipi di intervento in favore di una popolazione in difficoltà economica e sociale.

[ I 0] II primo murale caratterizza il fronte di un luogo volto ad accogliere i bambini più fragili, promuovendo l'incontro e l'inclusione di realtà ai margini, favorendo la ricucitura di legami familiari e della comunità. Il secondo invece, realizzato a Pisa su una parete cieca del Convento dei Frati Servi di Maria, è l'ultima opera realizzata dal noto artista, riconosciuta come Tuttomondo, nome proposto dall'autore dichiarando "Nemmeno questo dipinto ne ha uno, ma se dovesse avere un titolo sarebbe qualcosa come Tuttomondo".

\section{Riferimenti bibliografici}

Arnaldi V. (2014). Sulle tracce della street art. Viaggio alla scoperta dei più bei murales italiani. Roma: Red Star Press.

Bianchi F., Bani E. (2019). Pisa è Tuttomondo! II murale di Keith Haring raccontato alle nuove generazioni. Pisa: Marchetti Editore.

Colantonio R. (20 17). La Street art è illegale? II diritto all'arte di strada. Napoli: lemme edizioni.

Davico P. (2020). Colori dell'arte, colori dell'architettura, colori dello spazio urbano, colori per la sostenibilità. In V. Marchiafava, M. Picollo (a cura di). Colore e Colorimetria. Contributi Multidisciplinari, vol. XVI A, pp. 2I4-22 I. Milano: Gruppo del Colore Associazione Italiana Colore.

Davico P., Devoti C. (2020). Street art a Torino: una nuova immagine della città tra continuità storica e disegno urbano. Street Art in Torino: a New Image for the city between Historical Continuity and Urban Survey. In Di A. Luggo, O. Zerlenga (a cura di). Disegnare sui muri. Drawing on the walls, pp. 127-149. Napoli: La scuola di Pitagora.

Di Luggo A., Zerlenga O. (a cura di). (2020a). Disegnare sui muri. Drawing on the walls. Napoli: La scuola di Pitagora.

Di Luggo A., Zerlenga O. (2020b). Street art. Drawing on the walls. In Disegnarecon, n. 24, vol. I 3.

Dogheria D. (20I5). Street Art. Storia e controstoria, tecniche e protagonisti. Firenze: Giunti.

Fioretti M. (2020). Dal terremoto al Covid: la lunga solidarietà tra Bergamo e Lioni in due murales. <https://www.orticalab.it/ Dal-terremoto-al-Covid-la-lunga> (consultato il 25 novembre 2020).

Gastman R., Neelon C., Smyrski A. (2007). Street world. Urban culture from five continents. London:Thames \& Hudson.

Gianquitto M. (2019). Graffitismo \& Street Art. Brescia: Bellavite editore.

Liloia P. (2020). Street art a Lioni, i 'Legami' alla stazione firmati da Sena. IrpiniaPost: <http://www.irpiniapost.it/street-art-a-lioni-i-legami-alla-stazione-firmati-da-sena/> (consultato il 23 novembre 2020). 
Perelli L. (2017). Arte che non sembra arte. Arte pubblica, pratiche artistiche nella vita quotidiana e progetto urbano. Milano: Franco Angeli.

Pioselli A. (20 I5). L'arte nello spazio urbano. L'esperienza italiana dal 1968 a oggi. Monza: Johan \& Levi editore.

Proti L. (20 18). Messico e Stati Uniti: il murale di Chiu abbatte le distanze <https://www.travelonart.com/arte-contemporanea/ messico-stati-uniti-murale-di-chiu-abbatte-distanze/> (consultato il 30 novembre 2020).

Redazione Artemagazine (2017). Street art: il bambino del muro che rompe i confini <http://www.artemagazine.it/attualita/ item/5059-street-art-il-bambino-del-muro-che-rompe-i-confini> (consultato il 23 novembre 2020).

Sgobba V. (2019). Piergiorgio Castellani, Keith Haring e il murale Tuttomondo. Storia di un'amicizia. In Artribune, I 6 dicembre 2019. <ttps://www.artribune.com/professioni-e-professionisti/who-is-who/2019//2/piergiorgio-castellani-keith-haring-murale-tuttomondo-pisa/> (consultato il 7 gennaio 202I).

Street Art \& Urban Creativity Scientific Journal. (2017). SAUC Scientific Journal Knowledge Transfer, vol. 3/n. 2. <http://sauc.website/index.php/sauc/issue/view/7> (consultato il 20 gennaio 202I).

TOward 2030. L'arte urbana e lo sviluppo sostenibile (2019). Milano: Feltrinelli.

Zanella C. (2019). Milano, un murale per l'inclusione e la diversità: lo street artist Sonda dipinge con i ragazzi. La Repubblica, Milano: <https://milano.repubblica.it/cronaca/2019/04/I7/foto/milano_rozzano murale_inclusione_e_diversita_sonda_ragazzi_disagiati-224 I05946/ / /> (consultato il 27 novembre 2020).

\section{Autore}

Pia Davico, Politecnico di Torino, pia.davico@polito.it

Per citare questo capitolo: Davico Pia (2021). Connessioni tra città e immagini per tessere inediti legami sociali/Connections between cities and images to weave unprecedented social links. In Arena A. Arena M.. Mediati D. Raffa P. (a cura di). Connettere. Un disegno per annodare e tessere. Linguaggi Distanze Tecnologie Atti del $42^{\circ}$ Convegno Internazionale dei Docenti delle Discipline della RappresentazionelConnecting. Drawing for weav ing relationship. Languages Distances Technologies. Proceedings of the $42^{\text {th }}$ International Conference of Representation Disciplines Teachers. Milano: FrancoAngeli, pp. I 563- 1580 


\title{
Connections between Cities and Images to Weave Unprecedented Social Links
}

\author{
Pia Davico
}

Abstract

In recent times, cities are increasingly adopting Street Art in their urban and social regeneration projects, creating links between space, architecture and images, as well as between the city centre and its outskirts. These links are sometimes unintentional, created by fictitious visual routes, due to the search for and discovery of new aspects of the city, characterised by drawings that are usually large and full of colour, which take on a leading role in the environment. The various interventions, whether pursued intentionally as part of coordinated projects or spontaneous, all document a change in role of an art form which was considered illegal until just a few years ago and which today, with the meaningful characters of its spectacular designs, has become an engine for raising awareness in relation to social issues, moving the collective conscience much more than many words. In different ways, these creations create a real link between several components of the environment and its inhabitants, reflecting the words of the famous mathematician and physicist Jules Henri Poincaré, for whom "Creativity is to unite existing elements with new connections that are useful".

This wide-ranging general panorama encompasses a variety of experiences, united by intentions and meanings in which the word 'connection', the theme of the conference, is echoed in various forms of design; the city itself, through Street Art, gives voice to the desire to make society aware of the need to forge links (of various kinds) to bridge the gaps between man and the environment and between man and man.

Keywords

design, Street Art, urban space, connecting, social distances.

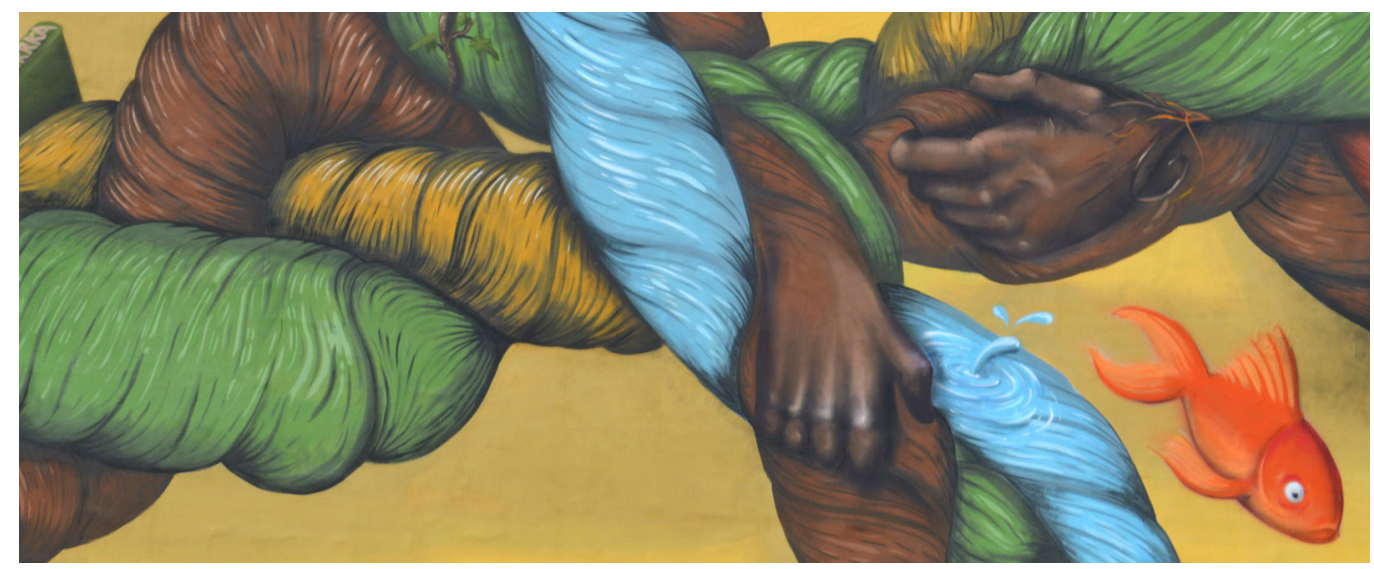




\section{Introduction}

An increasing number of cities are tackling new urban scenarios through Street Art, recognising its important role in catalysing new social and tourist dynamics and redeveloping rundown areas.

This type of art is still struggling to achieve full recognition in the sphere of art and legality, freeing itself from a past in which it was condemned as an act of vandalism [I]. Nevertheless, numerous countries and cities around the world are adopting it at an increasing pace, proposing projects for the improvement of locations and society, having understood and tested its positive impact, not only in terms of image. With increasing frequency, coordinated intervention projects (between street artists, public administrations and cultural associations) with a precise aim, as well as individual interventions on decaying buildings or bare walls, are being proposed at every level, from local to international. These buildings and walls are gradually becoming veritable open-air museums, characterised by a life cycle that changes over time, if only because of the deterioration of the works due to the weather.

Drawings and paintings generally characterise architectural elements that have no identity of their own -such as bare façades, dividing walls or abandoned buildings- giving them a new look and a new role within the urban space. The success of these works, however, is linked not only to the creation of a new environmental image, but also to the immediacy with which they convey messages, skilfully identified and interpreted by the artists, which reach people directly. These messages are often deliberately proposed in physically and socially rundown places, hoping to trigger improvement and redemption, bringing entire areas of cities and their inhabitants out of isolation; in many cases, the population is engaged in participatory projects or, more generally, attention is drawn to issues of collective interest, indirectly giving a voice to many people who don't otherwise have one.

Places and people obscured by a history that is often 'on the margins' are given a new identity, stimulated by the images and meanings of works that become hubs of the environment and of behavioural dynamics; this triggers processes that are open to scenarios of involvement in a variety of spheres, including tourism, also creating cultural and artistic connections between the city centre and the suburbs, with positive urban and social effects. Paths that link the works to each other and to parts of the city that have remained separate due to their history or conformation are created, either intentionally or accidentally.

I have selected some works from this reality, linked increasingly to urban regeneration, which offer different interpretations of a common desire: to mark the importance of social ties, arousing wonder and emotions, and also creating a phenomenon that confirms John Trackara's claim: "the most exciting cities are those where unexpected things happen, in unexpected places with a tendency to be unattractive and marginal" [2].

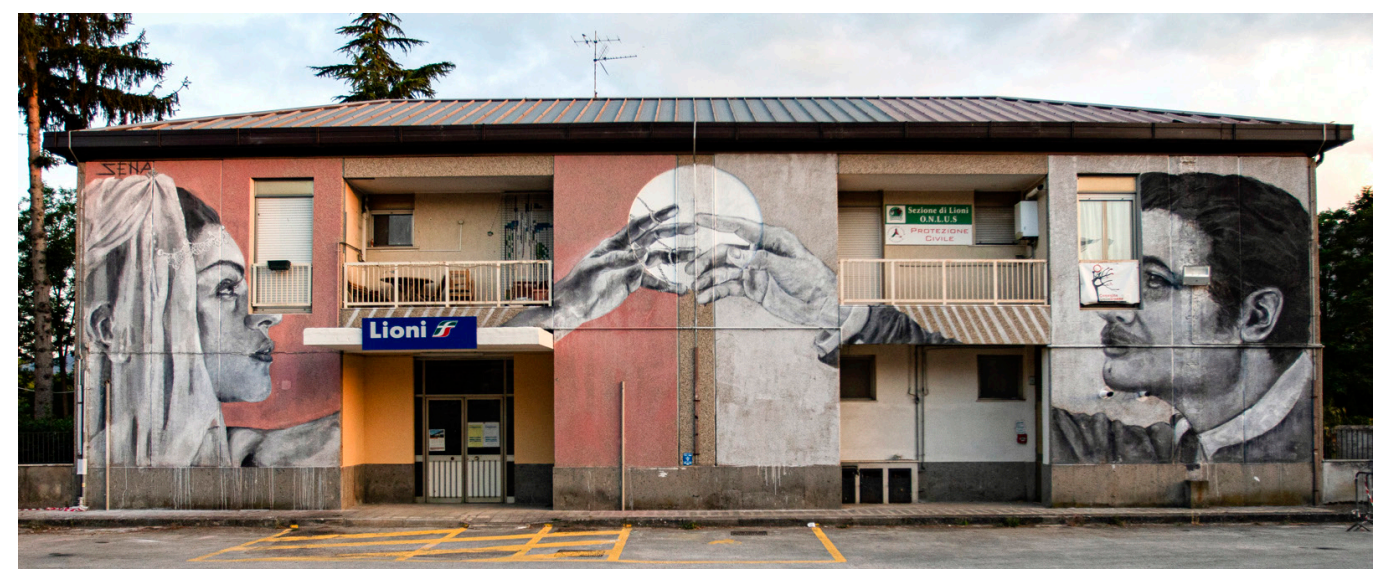




\section{Bridging the gaps between men}

The Irpinia earthquake is still very much alive in the collective memory: forty years on, the municipality of Lioni, together with the social promotion association La Prediletta, has recently created the urban art project 1980-2020 Prospettive d'autore. The "union between people" has been interpreted in two murals with different meanings: Legami by Antonio Sena and Folle by the Fx and NemO'S Collective. The first work (fig. I) is on the front of the railway station, in memory of those involved in the migratory exodus of the last century; it depicts the faces and hands of a man and a woman touching. The symbolism of the woman's face, covered in a veil, and her hand, tied up with a cord, reflects the condition of women in rural southern societies, when marriage by proxy was frequent and marked lives by separations and reunions. A caesura between a before and an after which can also be found in the other work of urban art in Lioni (fig. 2) in the Campo Bergamo working-class area, and which is interesting in the way it proposes a design that can be interpreted on several levels. It is a work of great significance, which eliminates distances and emphasises and modernises the consolidated bond of solidarity with the Lombard town of Bergamo that supported the creation of the homonymous district in Irpinia after the earthquake; a town that has suffered particularly this year due to the Covid pandemic, to which Lioni symbolically shows its support in the mural. The drawing shows two hands stretched out to shake each other, which are actually made up of hundreds of little men in representation of the two communities, linked in a virtual embrace [3].

An embrace which, on the contrary, has been materially denied for the past few years, is that prevented by the construction of the wall between Mexico and the United States, and various street artists, such as Enrique Chiu, whose Mural of brotherhood project turned it into a backdrop brought to life by drawings and writings promoting unity and peace (fig. 3) [4], have responded to this. In 2017, for one month, the same wall hosted the more controversial work by French writer Jr, with the giant picture of a little Mexican boy, Kikito, who looks out from his country over the long wall that runs for kilometres along the border separating Mexico from San Diego, imposing itself on the landscape (fig. 4). Due to its huge size (it stands twenty metres tall) and its strong expressiveness, the image has become a symbol against division and has subverted the impact of that barrier which has separated lives and divided affections, configuring the desire by so many not to accept the wall and, more generally, the barriers that prevent contact and the freedom of human beings.

Fig. 2. Fx Collettive and NemO'S, Folle, Lioni < ht tps://www.irpinianews.it/ foto-lioni-bergamo-un-legame-che-non-si-spezzagame-che-non-si-spezza-
nel-nuovo-murale-folle/> (accessed 2021, March 20).

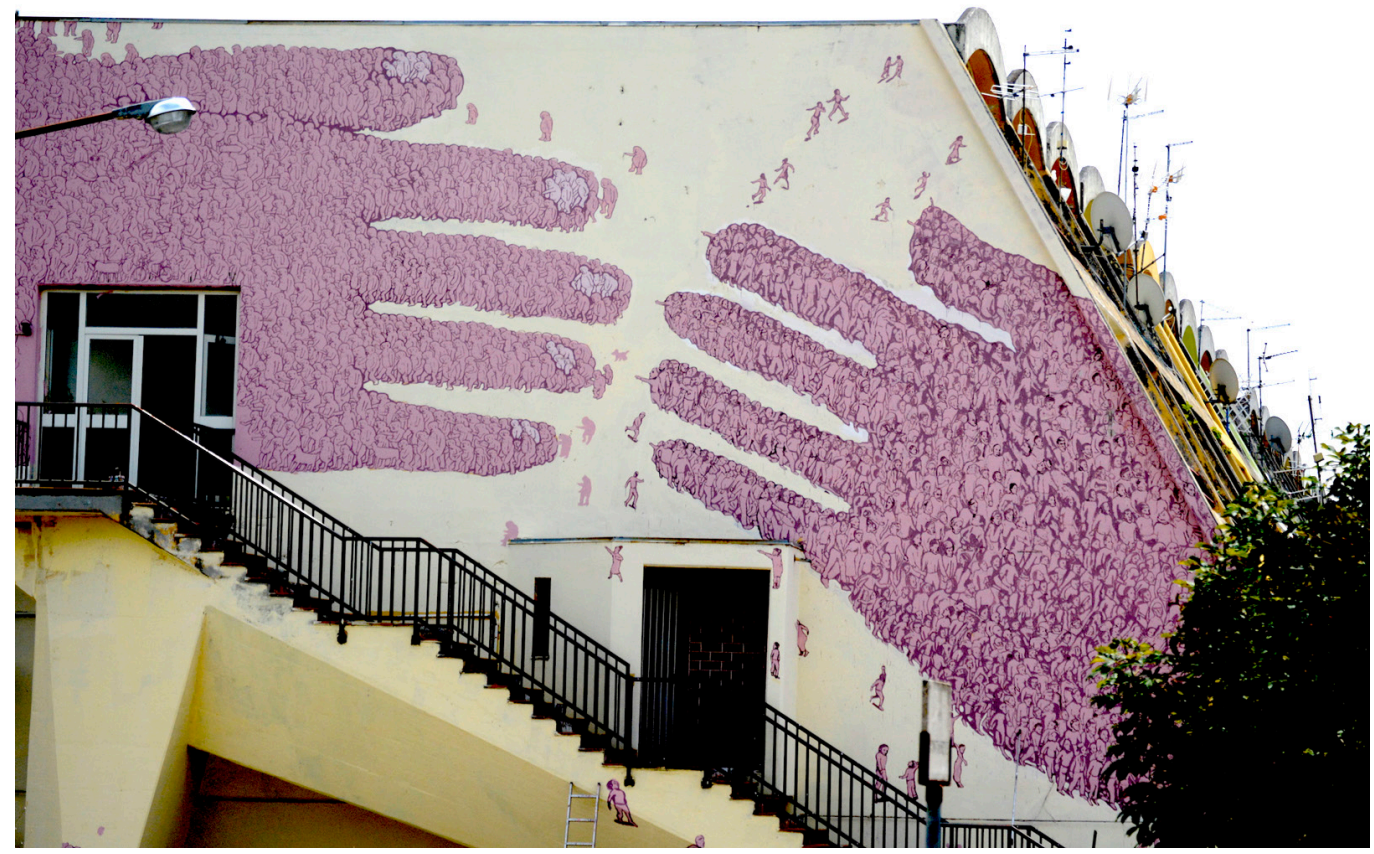


Fig. 3. Enrique Chiu, Mural of brotherhood, wall between Mexico and the United States <https://thevalemagazine. com/20 19/07/07/muralof-brotherhood-enriquechiu-us-mexico-border/> (accessed 2021, March 20).

Fig. 4. Jr, Kikito, wall between Mexico and the United States <https. youmedia.fanpage.it/ gallery 79786 ffo $>$ (accessed 2021, March 20).

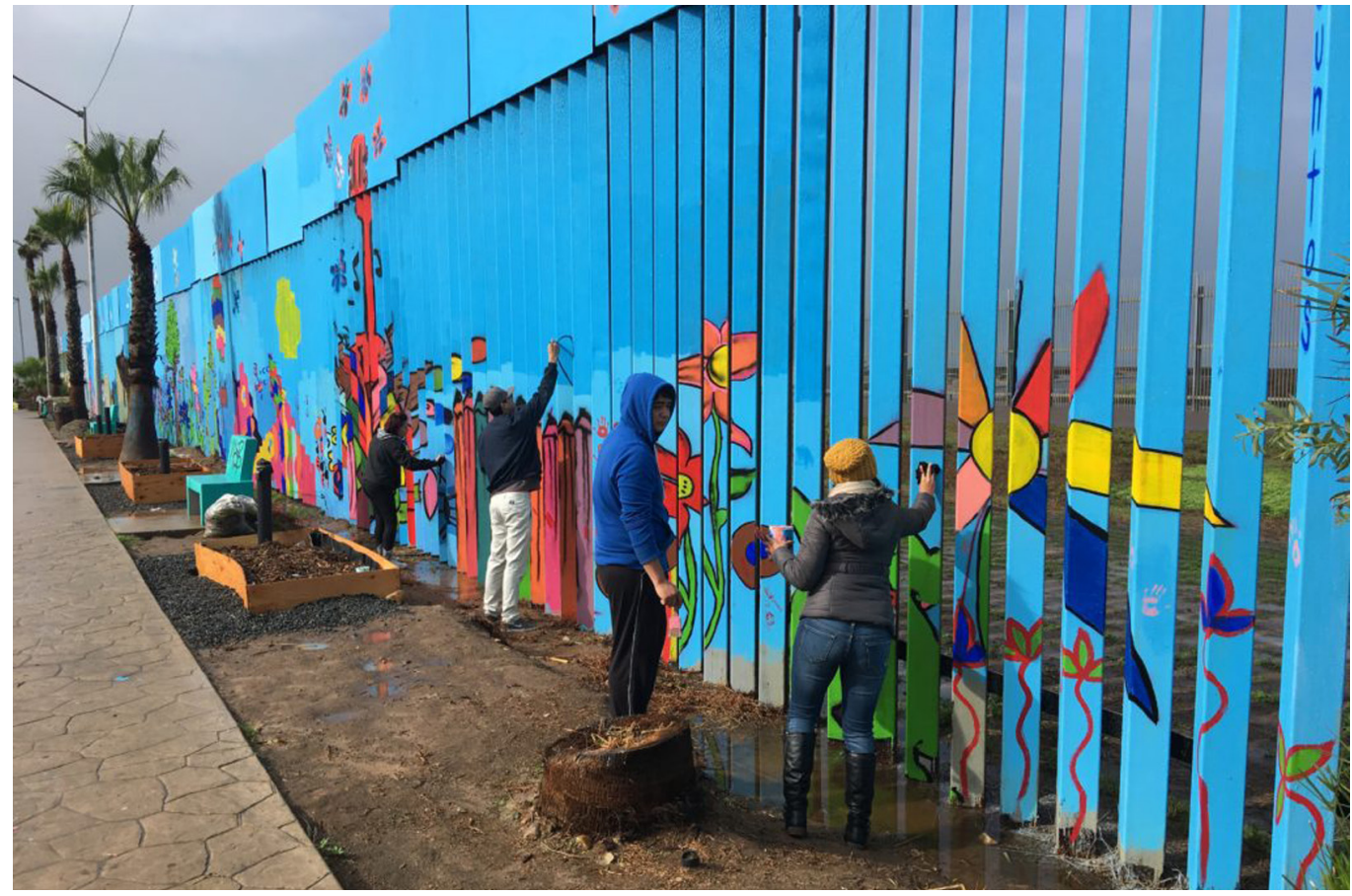

In addition to these physical divisions, there are also invisible barriers that separate people, resulting from social problems, often overcome with urban art projects that break down their negative dynamics. A case in point is the recent intervention in the Palmitas neighbourhood of the Mexican city of Pachuca, a collaboration between the government and the Germen Crew and Comex collective, which has created cohesion in the local community and reduced violence among young people (fig. 5). A huge mural painted by writers and by the local people has embraced the houses and streets in a rainbow of colours, personalising the landscape by articulating the entire urban nucleus, and every spot and individual building within it, on a hill, marking out the identity of the place and of its people, whose homes are part of a unicum within a community [5]. The apparent simplicity of this project, carefully placed in a reality where colour is a culturally rooted element, finds deep meaning in the words of American anthropologist Jane Jacobs, who says: "Designing a dream city is easy [...] Rebuilding a living one takes imagination" [6].

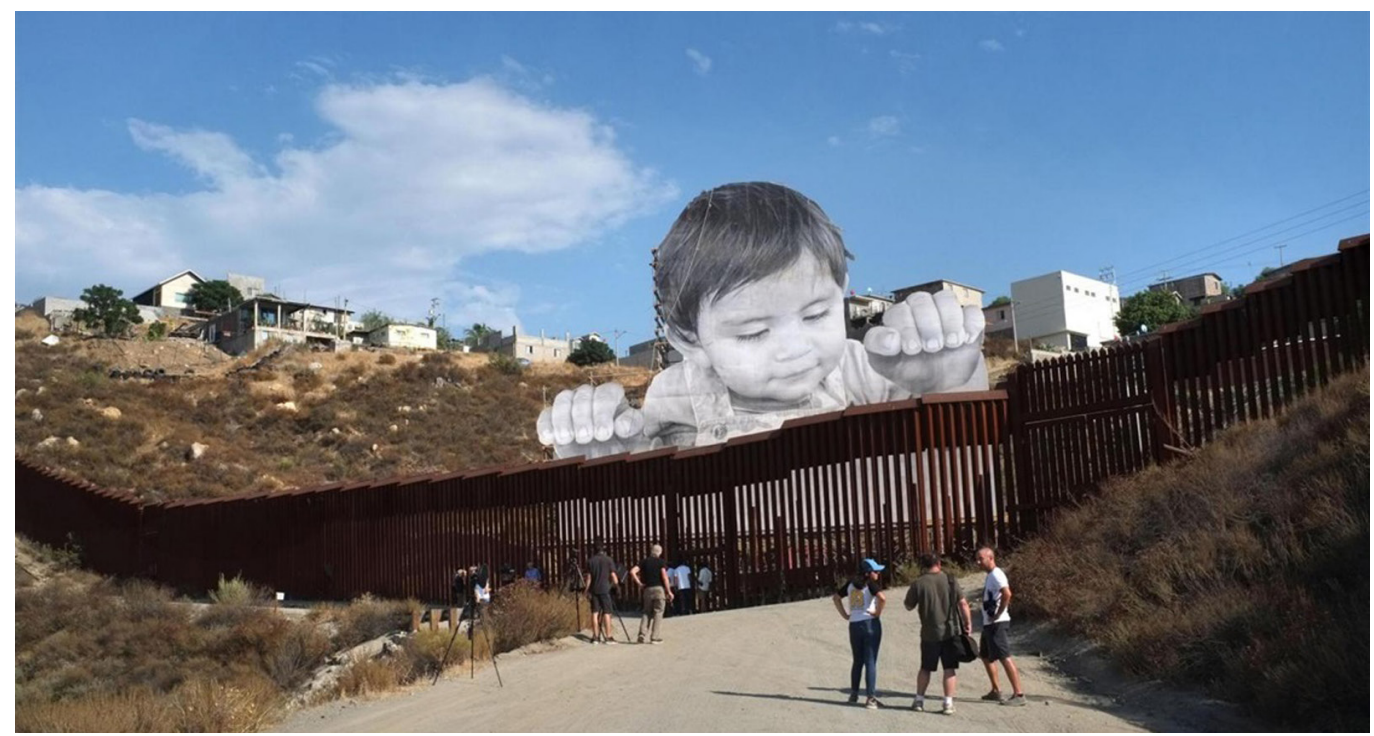


Fig. 5. Germen Crew and Comex Collective, Palmitas neighbourhood, Pachuca (Mexico) <https:// danatahal l.wordpress. $\mathrm{com} / 2015 / 08 / 04)$ germen-crew-creates-aglant-piece-in-pachucamexico/>, <https:// foolsjournal2.wordpress. com/2017/04/13/streetart-la-citta-arcobalenodel-messico/> (accessed 2021, March 20).
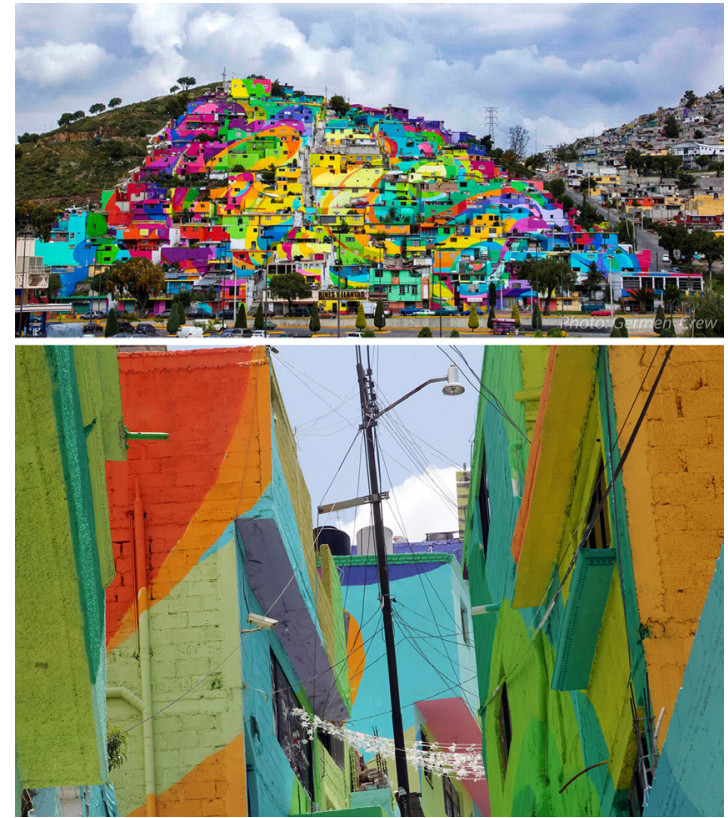

\section{Repairing the tears in the life of an emigrant}

Among the gaps in today's society, that created by emigration is as topical as ever, and is the subject of numerous woks of urban art in Italy and around the world, aimed at drawing attention to a widespread human drama that seems to know no end. Among the many, I propose The Mediterranean tunnel by French street artist MTO (fig. 6), which is particularly representative and original in the way it creates a link between two coasts, forced to share the refugees or their corpses. It is a work 'split' on the fronts of buildings in two cities, connected by a meaningful project that interprets "divisions". On the wall of a house in Sliema (on the east coast of Malta), the legs of a man struggling to get inside emerge from a slit,
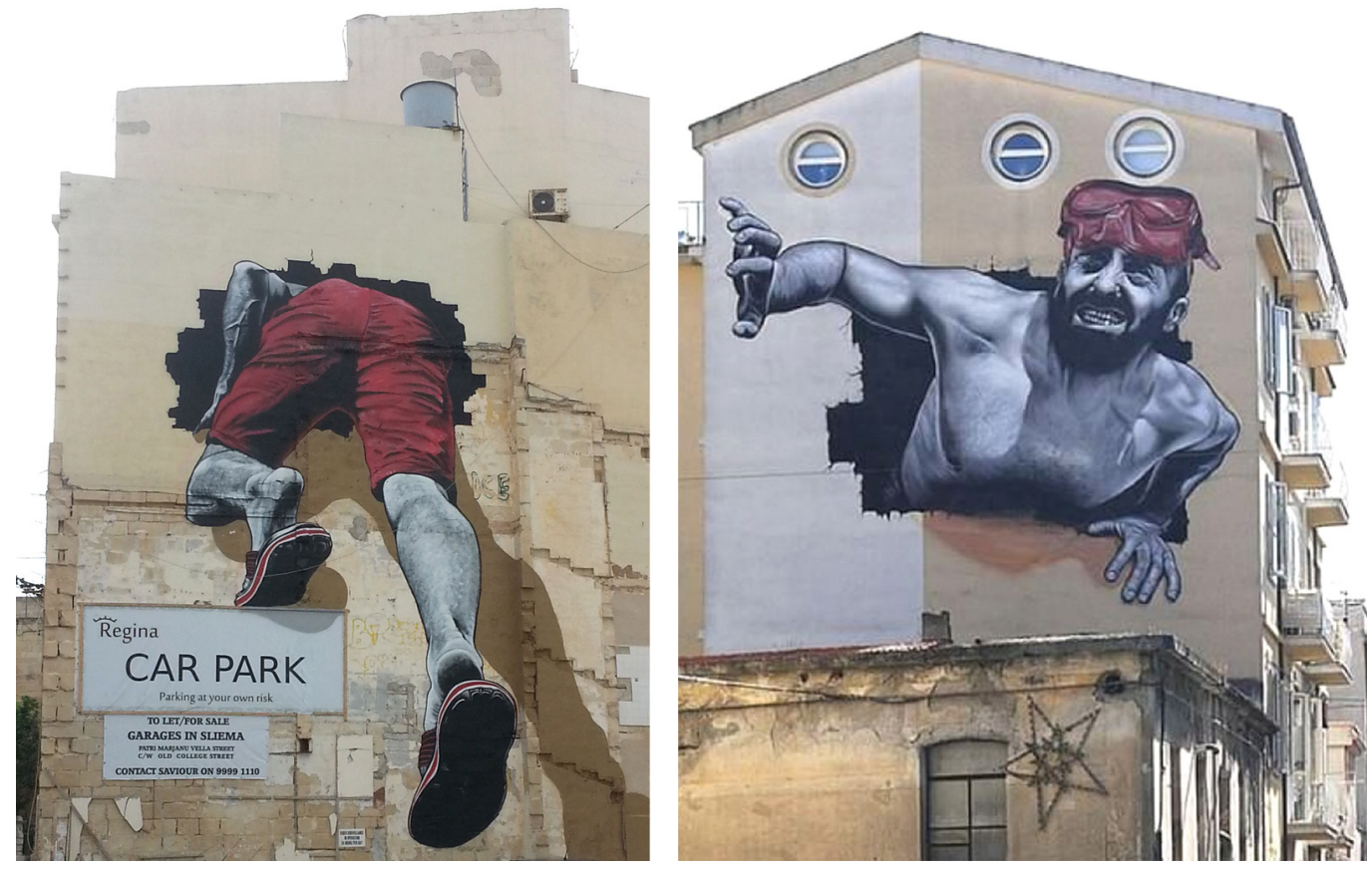
Fig. 7. Smoe, Emigrants, Catanzaro <http:// www.smoe.it/outdoor/ emigranti/> (accessed 2021, March 20).

Fig. 8. Smoe, Meridianam Catanzaro <https:// www.citynow.it/ riace-nel-mondo-spiccamelbourne-murale-

made-calabria marchiatosmoel> (accessed 2021 March 20). while six hundred kilometres away, on a façade in Sapri (on the coast of Salerno), a refugee emerges from a crack, his face etched with pain as he struggles to free himself.The double drawing synthesises the reality, broken by a long and dangerous journey, and simultaneously creates a virtual long-distance link, marked by a gestural expressiveness that imposes itself, characterising the surrounding environment, subduing its architectural features.

Among the many works on the subject of emigration, which would deserve further investigation due to the way they highlight the priority of interest, graphic and otherwise, in the subject, I would like to mention Emigrants (fig. 7), a mural by Smoe (unfortunately already subject to deterioration), which has created, with a skilful work of perspective, a link between the migratory flows of the past and those of the present on a plain retaining wall in Catanzaro. Its creator has dedicated the more recent Meridianam (fig. 8) to those of the present, using the images to give voice to the most recent phenomenon, swollen with immense pain and inhuman tragedies [7].
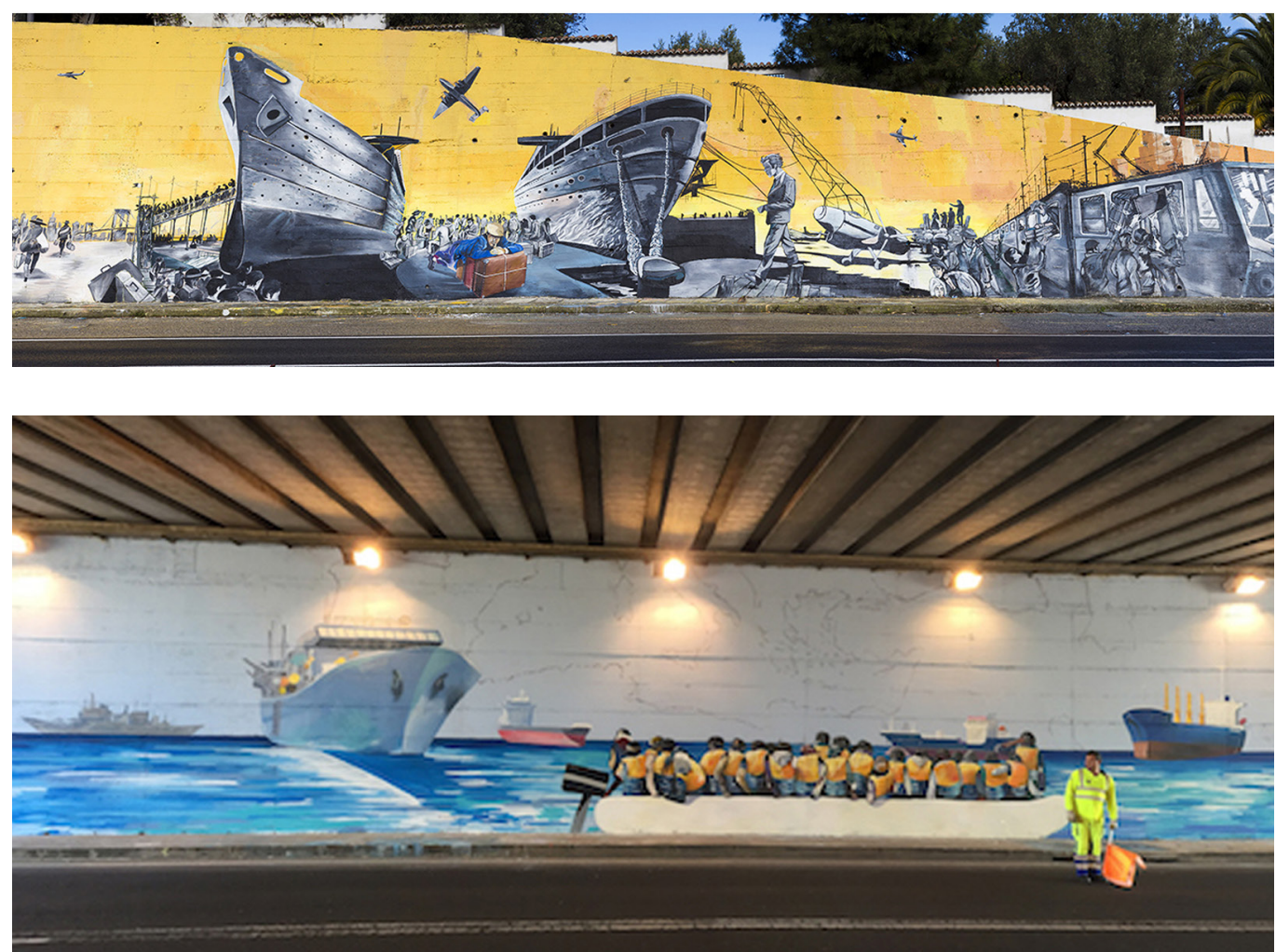

Creating links between people, the city, the world

Drawings, colours and images capable of generating the visual, cultural and social links mentioned above from nothing, with their strong communicative intensity, expand beyond their material confinement, creating new wide-ranging relationships that sometimes take on a global dynamic. The international success of Street Art in disseminating themes involving communities can be found in numerous projects with different features and different aims. Here, I propose some which emphasise the importance of the links between people, their surroundings and the rest of the world, in different ways. I would like to start with an image that enhances this meaning, from the complex Street Art project TOward 2030. What are you doing? which, since 2019, has installed works interpreting the UN's Sustainable Development Goals in Turin's urban fabric [8]. The mural of Goal 17 Partnerships for the goals (fig. 9), by Monkeys Evolution, characterises not only the blank façade of a building but the entire surrounding area, with a bright yellow background of coloured ropes and linked hands. The 
Fig. 9. Monkeys Evolution, Goal 17 - Partnerships for the goals, Torino (foto by Pia Davico, July 2020).

Fig. 10. Work from Murales Resilienti, REACT project, Guatemala <https://www.weworld.it/ liniziativa-dei-murales-resilienti/> (accessed 2021, March 20)
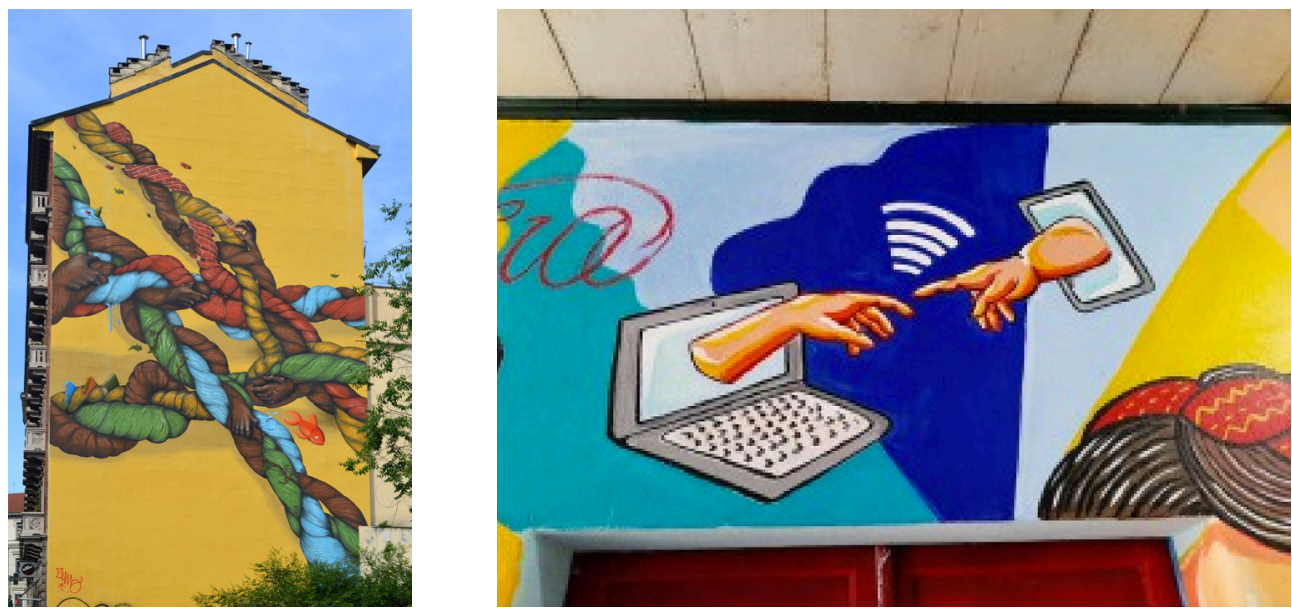

work, installed at number 20 Corso Giulio Cesare, in an area of the city that welcomes immigrants from various ethnic groups, symbolically emphasises how the network of joint actions by people of different 'colours' enriches our society and culture and, at specific level, makes it possible to achieve every Goal, both locally and globally.

The similar goal of uniting values and overcoming distances with social projects that use urban art to reach out to everyone can be seen in the Murales Resilienti project brought to life in Guatemala in recent months: eight works by young local writers that promote values of resilience and solidarity, inspiring human relationships and mutual aid. Distinguished by its originality in dealing with the moment the world is experiencing due to the Covid pandemic, the mural playfully cites Michelangelo's Creation of Adam in the Sistine Chapel, portraying two hands intent on touching each other as they emerge from computer and tablet screens. It emphasises the fundamental role played by technology in bridging the gaps between people during the pandemic isolation [9] (fig. I0).

I would like to end by mentioning two more murals, of different origins and from different times, which exalt the added value of the union between human beings, created in one case by Cristian Sonda with the kids from Casa per fare insieme in Rozzano (MI) (fig. I I), and, in the other, by the internationally renowned artist Keith Haring, in Pisa (fig. 12). Years apart (the first was created a few months ago, the other in 1989), they both emphasise the beauty of a community enriched by the diversity of people, with airy, brightly coloured drawings, providing educational input and raising awareness [10].

These internationally stimulating goals are always promoted by images with strong symbolism, the success of which lies in the amazement they arouse, in the immediacy of their communication, and in often providing a ray of hope, especially for those environments suffering the consequences of abandonment.

Fig. II. Cristian Sonda and children from the Casa per fare insieme Rozzano (MI) < https:// zh-cn.facebook.com/casaperfareinsiemerozzano/ posts/grazie-cristian-sonda-e-grandi-ragazze-e-ragazzi-della-casa-texere/321980031785885/> accessed 2021, March 20).

Fig. 12. Keit Haring Tuttomondo, Pisa <https:// Tuttomondo, Pisa https mad.com/keith-harnomad.com/kelth-harings-pisa-muraltuttomind 20).
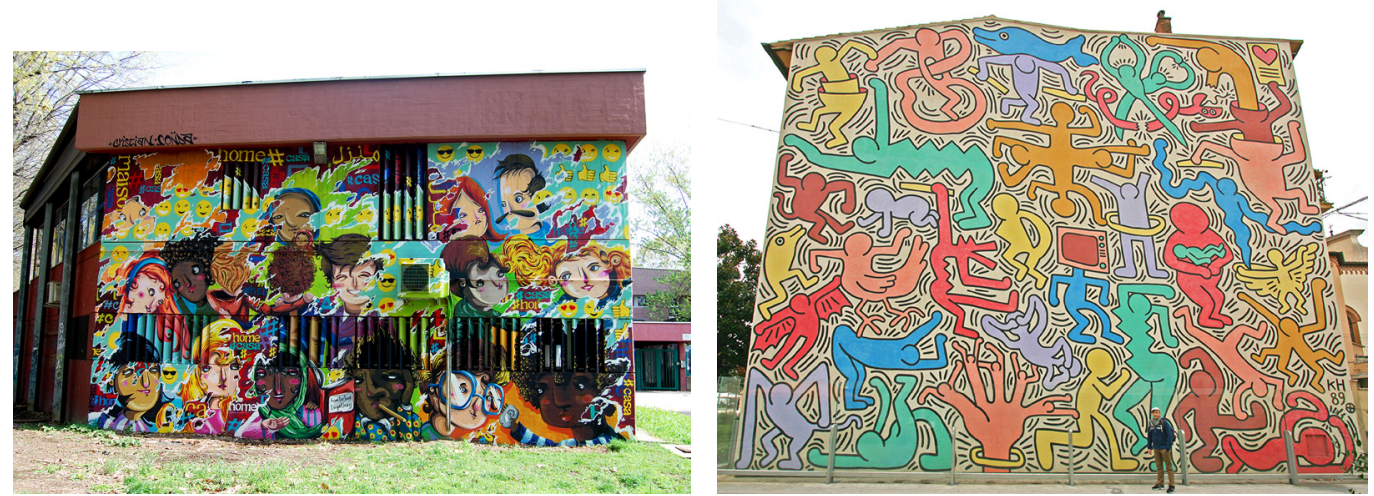
They are images that create a strong bond of identification with people and cities: the works become the protagonists of a new environmental identity, in which the features of the architecture are blurred, becoming simple supports for large urban 'canvases'. Their meanings insinuate themselves as an element of denunciation and hope into people's lives and into the dynamics of the city, with that creativity which, in the words of Jules Henri Poincaré, consists in "uniting existing elements with new connections that are useful".

\section{Notes}

[I] For further details on this aspect see: Colantonio 2017.

[2] inforum. Information on Urban and Territorial Redevelopment, no. 39, 2012, p. 33.

[3] Lioni proposes other murals in addition to these, entering Google Art's Urban Museums circuit for the new tourist flow created by Street Art. Since 2014, it has become known for its urban art festival, attentive to various social issues (such as the two murals by Dale Grimshaw which sparked controversy in 2018 by proposing the particularly topical theme of modern-day migrants).

[4] The project, which involved thousands of volunteers for about two years from 2017, extends for a thousand kilometres, embodying Chiu's belief that "art is an opportunity to say things that cross the line".

[5] The mural, created to change the fate of a rundown neighbourhood, covers an area of 20,000 square metres, involving more than two hundred houses.

[6] The specific theme of colour as a characterising element of urban nuclei is dealt with in: Davico Pia, 20 I 3. The structuring role of colour in characterising urban areas. In Rossi M., Siniscalco A. (Eds.). Colore e colorimetria. Contributi multidisciplinari (Colour and colorimetry. Multidisciplinary contributions), vol. IX A, pp. 389-400. Santarcangelo di Romagna: Maggioli editore.

[7] Smoe is a street artist from Catanzaro, active in various parts of the world on the themes of immigration and minorities In Meridianam he focused his attention on modern-day migration in the Mediterranean and mass migration by young people from southern ltaly in search of work.

[8] The project, born from the agreement between the City of Turin and Lavazza, launched in January 2020, placed murals both in the city centre and on its outskirts, to create extensive involvement in the specific themes of sustainability, projecting Turin into a global debate, as the first metropolis in the world to become ambassador of the United Nations' 17 Sustainable Development Goals.

[9] The initiative is part of a broad-ranging humanitarian aid project involving several organisations, with various types of intervention in favour of a population in economic and social difficulty.

[I0]The first mural characterises the front of a building designed to welcome the most fragile children, promoting socialisation and the inclusion of those who are relegated to the margins of life, encouraging reunification of families and the community. The second, created in Pisa on a blank wall of the Monastery of the Servite Friars of Mary, is the latest work by the well-known artist, recognised as Tuttomondo, a name suggested by the author, who declared: "This painting does not have one either, but if it did have a title, it would be something like Tuttomondo".

\section{References}

Arnaldi V. (2014). Sulle tracce della street art. Viaggio alla scoperta dei più bei murales italiani. Roma: Red Star Press.

Bianchi F., Bani E. (2019). Pisa è Tuttomondo! II murale di Keith Haring raccontato alle nuove generazioni. Pisa: Marchetti Editore.

Colantonio R. (20 I7). La Street art è illegale? II diritto all'arte di strada. Napoli: lemme edizioni.

Davico P. (2020). Colori dell'arte, colori dell'architettura, colori dello spazio urbano, colori per la sostenibilità. In V. Marchiafava, M. Picollo (a cura di). Colore e Colorimetria. Contributi Multidisciplinari, vol. XVI A, pp. 2I4-22 I. Milano: Gruppo del Colore Associazione Italiana Colore.

Davico P., Devoti C. (2020). Street art a Torino: una nuova immagine della città tra continuità storica e disegno urbano. Street Art in Torino: a New Image for the city between Historical Continuity and Urban Survey. In Di A. Luggo, O. Zerlenga (a cura di). Disegnare sui muri. Drawing on the walls, pp. 127-149. Napoli: La scuola di Pitagora.

Di Luggo A., Zerlenga O. (a cura di). (2020a). Disegnare sui muri. Drawing on the walls. Napoli: La scuola di Pitagora.

Di Luggo A., Zerlenga O. (2020b). Street art. Drawing on the walls. In Disegnarecon, n. 24, vol. I 3.

Dogheria D. (2015). Street Art. Storia e controstoria, tecniche e protagonisti. Firenze: Giunti.

Fioretti M. (2020). Dal terremoto al Covid: la lunga solidarietà tra Bergamo e Lioni in due murales. <https://www.orticalab.it/ Dal-terremoto-al-Covid-la-lunga> (accessed 2020, November 25).

Gastman R., Neelon C., Smyrski A. (2007). Street world. Urban culture from five continents. London:Thames \& Hudson.

Gianquitto M. (2019). Graffitismo \& Street Art. Brescia: Bellavite editore.

Liloia P. (2020). Street art a Lioni, i 'Legami' alla stazione firmati da Sena. IrpiniaPost: <http://www.irpiniapost.it/street-art-a-lioni-i-legami-alla-stazione-firmati-da-sena/> (accessed 2020, November 23). 
Perelli L. (2017). Arte che non sembra arte. Arte pubblica, pratiche artistiche nella vita quotidiana e progetto urbano. Milano: Franco Angeli.

Pioselli A. (20 I5). L'arte nello spazio urbano. L'esperienza italiana dal 1968 a oggi. Monza: Johan \& Levi editore.

Proti L. (2018). Messico e Stati Uniti: il murale di Chiu abbatte le distanze <https://www.travelonart.com/arte-contemporanea/ messico-stati-uniti-murale-di-chiu-abbatte-distanze/> (accessed 2020, November 30).

Redazione Artemagazine (20 17). Street art: il bambino del muro che rompe i confini <http://www.artemagazine.it/attualita/ item/5059-street-art-il-bambino-del-muro-che-rompe-i-confini> (accessed 2020, November 23).

Sgobba V. (2019). Piergiorgio Castellani, Keith Haring e il murale Tuttomondo. Storia di un'amicizia. In Artribune, I 6 dicembre 2019. <ttps://www.artribune.com/professioni-e-professionisti/who-is-who/2019//2/piergiorgio-castellani-keith-haring-murale-tuttomondo-pisa/> (accessed 2021, January 7)

Street Art \& Urban Creativity Scientific Journal. (2017). SAUC Scientific Journal Knowledge Transfer, vol. 3/n. 2. <http://sauc.website/index.php/sauc/issue/view/7> (accessed 202I, January 20).

TOward 2030. L'arte urbana e lo sviluppo sostenibile (2019). Milano: Feltrinelli.

Zanella C. (2019). Milano, un murale per l'inclusione e la diversità: lo street artist Sonda dipinge con i ragazzi. La Repubblica, Milano: <https://milano.repubblica.it/cronaca/2019/04/I7/foto/milano_rozzano_murale_inclusione_e_diversita_sonda_ragazzi_disagiati-224 I05946/I/> (accessed 2020, November 27).

\section{Author}

Pia Davico, Politecnico di Torino, pia.davico@polito.it

To cite this chapter. Davico Pia (202I). Connessioni tra città e immagini per tessere inediti legami sociali/Connections between cities and images to weave unprecedented social links. In Arena A., Arena M., Mediati D., Raffa P. (a cura di). Connettere. Un disegno per annodare e tessere. Linguagg Distanze Tecnologie. Atti del $42^{\circ}$ Convegno Internazionale dei Docenti delle Discipline della Rappresentazione/Connecting. Drawing for weaving relationship. Languages Distances Technologies. Proceedings of the $42^{\text {th }}$ International Conference of Representation Disciplines Teachers. Milano: FrancoAngeli, pp. $1563-1580$. 